\title{
Peran Parik Paga dalam Menjaga Ketertiban dan Keamanan Nagari Sungai Pua
}

\author{
Septri Aizil, Akmal \\ Program Studi Pendidikan Pancasila dan Kewarganegaraan \\ Universitas Negeri Padang \\ E-mail: aizilsepthree@gmail.com
}

\begin{abstract}
ABSTRAK
Parik Paga sebagai lembaga yang menjaga ketertiban dan keamanan yang kurang berjalan merupakan alasan utama dalam penelitian ini. Dalam pelaksanaanya masih ada kekurangan-kekurangan jika dilihat dari data yang ada. Artikel ini bertujuan untuk mengeksplorasi pelaksanaan peran Parik Paga dalam menjaga ketertiban dan keamanan, hambatan-hamabatan hingga upaya mengatasi hambatan-hambatan tersebut. Penelitian ini menggunakan pendekatan kualitatif deskriptif dengan informan walinagari, ketua Parik Paga, anggota Parik Paga, Datuak Penghulu, dan masyarakat yang dipilih secara purposive. Data penelitian dikumpulkan dengan observasi dan wawancara dengan menggunakan langkah-langkah pengolahan data kualitatif. Hasil penelitian menunjukkan pelaksanaan peran Parik Paga masih kurang optimal karena masih belum melakukan sosilisasi secara langsung kepada masyarakat, kualitas sumber daya manusiapun masih minim terlihat dari perekrutan anggota tidak melalui seleksi. Sedangkan hambatan Parik Paga tersebut yaitu anggaran dana tidak ada fasilitas sarana dan prasarana masih kurang dan regulasi belum diatur. Mengatasi hal tersebut beberapa upaya yang dapat dilakukan oleh pemerintahan nagari dan Parik Paga hambatan-hambatan tersebut terselesaikan adalah mensosialisasikan kepada masyarakat secara langsung Parik Paga tersebut, membuat regulasi-regulasi tentang anggaran dana, fasilitas sarana prasarana maupun regulasi yang belum diatur serta mengadakan pelatihan untuk Parik Paga.
\end{abstract}

\section{Kata Kunci: Parik Paga, ketertiban dan keamanan, Sungai Pua}

\section{ABSTRACT}

Parik Paga as an institution maintains order and security is not running is the main reason in this research, in implementation there are still shortcomings when viewed from existing data. This article aims to exploit implementation the role of Parik Paga in maintaining order and security, barriers to efforts to overcome these obstacles. This study used a descriptive qualitative approach with informants walinagari, head of Parik Paga, members of Parik Paga, Datuak Penghulu, and the community chosen purposively. Research data were collected by observation and interview using qualitative data processing steps. The results showed that implementation of the role of Parik Paga was still not optimal because it had not yet conducted direct socialization to the community, the quality of human resources 
was still minimal as seen from the recruitment of members not through selection. Meanwhile, the barriers to paga are that the budget for funds does not have facilities is still lacking and regulations have not been regulated. Overcoming this, several efforts that can be carried out by the nagari government and Parik Paga these obstacles are resolved by directly socializing the community, making regulations on budget funds, facilities and unregulated regulations and conducting training for Parik Paga.

\section{Keywords : Parik Paga, security, Sungai Pua}

This work is licensed under the Creative Commons Attribution-ShareAlike 4.0 International License. (C)2019 by author.

\section{PENDAHULUAN}

Penelitian mengenai pelaksanaan peran Parik Paga dalam menjaga ketertiban dan keamanan masyarakat Nagari Sungai Pua penting dan menarik dikarenakan beberapa alasan. Pertama, Parik Paga merupakan suatu kebutuhan masyarakat terutama masyarakat nagari dalam menjaga ketertiban dan keamanan karena nagari memiliki otonomi sendiri menciptakan lembaga kemasyarakatan nagari. Kedua, Parik Paga kebutuhan nasional dimana di berbagai daerah, juga peran Parik Paga hanya saja dalam nama yang berbeda seperti pecalang pada daerah Bali (Sanjaya, 2017).

Parik Paga ini merupakan salah satu lembaga cerminan dari adanya otonomi daerah sampai ketingkat desa atau nigari. Parik Paga difungsikan sebagai suatu unsur atau lembaga yang bertugas menjaga ketertiban masyarakat nigari.

Parik Paga juga terdapat pada daerah lain dengan nama yang berbeda seperti Bhayangkara Pembinaan Keamanan dan Ketertiban Masyarakat (BHABINKAMTIMAS) di Kelurahan Mugirejo (Azhari, 2018), Pecalang di Desa Kalubukbuk (Sanjaya, 2017), SATLINMAS di Kelurahan Gilingan (Kinasih, 2018) dan Bintara Pembina Desa (BABINSA) di Desa Setualang dan Desa Gong Solok (Yohannes, 2015).

Penelitian di atas masih memiliki keterbatasan pasalnya belum ada penelitian secara lebih mendalam terkait dengan pelaksanaan dari peran pelaksana yang menjaga ketertiban dan keamanan desa atau nagari tersebut. Beberapa penelitian diatas hanya menjelaskan atau mengidentifikasi apa saja tugas dan wewenang dari pelaksana peran bukan bagaimana pelaksanaannya dan juga penelitian diatas ada beberapa yang masih tidak memberikan solusi terhadap hambatan atau faktor penghambat pelaksana peran. Penelitian terkait pelaksanaan peran Parik Paga dalam menjaga ketertiban dan keamanan masyarakat Nagari Sungai Pua ini dilakukan dikarenakan Nagari Sungai Pua sebagai Nagari di Kabupaten Agam yang mendapatkan peringkat pertama dari 82 nagari yang lain kontradiksi dengan keadaan nagari yang masih adanya kasus perjudian yang sering terjadi pada saat malam alek datuak, dan masih adanya rental playstation yang pada Peraturan Nagari Sungai Pua No. 8 Tahun 2008 tentang Ketertiban dan Keamanan Masyarakat rental playstation tersebut harus dihentikan oleh Parik Paga.

Solusi yang ada sebelumnya belum sepenuhnya menyelesaikan 
permasalahan dalam pelaksanaan dari Parik Paga tersebut karena solusi yang di tawarkan masih dalam bentuk pelatihan yang ditujukan kepada Parik Paga agar Parik Paga memiliki kecerdasan spiritual dan kecerdasan emosional. Sedangkan permasalahan dari tidak berjalannya peran Parik Paga tersebut terletak pada dana atau anggaran yang tidak cukup.

Solusi yang peneliti tawarkan adalah adanya anggaran dana yang cukup dan fasilitas sarana prasarana yang lengkap yang diperoleh melalui pembuatan regulasi atau aturan, dalam aturan tersebut nantinya dijelaskan anggaran dana dan fasilitas sarana dan prasarana tersebut di dapatkan darimana, kapan, untuk siapa dan apa saja. Jika hal tersebut sudah terpenuhi maka sosialisasi dan peningkatan kapasitas dan kapabilitas Parik Paga baru dapat dilakukan. Tujuan dari penelitian ini adalah untuk mengesplorasi pelaksanaan peran Parik Paga dalam menjaga ketertiban dan keamanan masyarakat Nagari Sungai Pua serta hambatan dan solusinya. Penelitian ini berguna untuk bahan evaluasi kinerja Parik Paga oleh pemerintahan nagari dan wadah bagi masyarakat untuk mengenal lebih jauh tentang Parik Paga.

\section{METODE PENELITIAN}

Penelitian ini adalah jenis penelitian kualitatif. Informan penelitian dilakukan dengan purposive sampling yang berjumlah walinagari, ketua Parik Paga, anggota Parik Paga, anggota DPRD Kabupaten Agam , 4 orang Datuak Penghulu dan masyarakat. Penelitian dilakukan di Nagari Sungai Pua Kecamatan Sungai Pua Kabupaten Agam. Jenis data yang digunakan dalam penelitian ini adalah data primer dan data sekunder. Pengumpulan data dilakukan dengan wawancara tidak terstruktur, observasi dan studi dokumentasi. Uji keabsahan data dengan menggunakan teknik trianggulasi data. Teknik analisis data dilakukan dengan tahapan pengumpulan data, reduksi data, penyajian data dan mengambil kesimpulan atau verifikasi data. Waktu observasi dan penelitian kurang lebih tiga bulan.

\section{HASIL DAN PEMBAHASAN}

Pelaksanaan peran Parik Paga dalam menjaga ketertiban dan keamanan di Nagari Sungai Pua

Penelitian menggunakan Teori

Edward III dalam menganalisis pelaksanaan peran Parik Paga dalam menjaga ketertiban dan keamanan di Nagari Sungai Pua dimana terdapat empat variabel yaitu komunikasi, sumber daya manusia, disposisi, dan struktur birokrasi. Berdasarkan variabel komunikasi pemerintahan nagari dan Parik Paga belum melakukan kegiatan sosilisasi kepada masyarakat secara langsung dan khusus, komunikasi yang dilakukan pemerintahan nagari dan Parik Paga yang bersifat tidak langsung mengakibatkan masyarakat tidak begitu mengatahui dan sadar akan adanya Parik Paga, sehingga untuk variable komunikasi belum terlaksana dengan maksimal.

Sebagaimana penelitian dari Prasetyo (2014) menjelaskan bahwa audiens atau masyarakat harus paham dengan apa tugas dan wewenangnya agar pelaksana peran tersebut karena komunikasi sangat menentukan keberhasilan dari pelaksanaan peran tersebut, dengan demikian untuk 
meningkatkan efektifitas pelaksanaan peran Parik Paga dapat dikomunikasikan atau disosialisasikan secara langsung kepada masyarakat baik mengenai tugas dan wewenang maupun peraturan-peraturan yang ada agar masyarakat mengetahui kemana harus mengadukan permasalahan yang berkaitan dengan ketertiban dan keamanan dan sejauh mana permasalahan masyarakat yang dihadapi dilaporkan kepada Parik Paga. Seperti yang dikatakan Lasswell (Wenxiu, 2015: 245) yang menyatakan bahwa komunikasi pada dasarnya merupakan suatu proses yang menjelaskan apa? Mengatakan apa? Dengan saluran apa? Kepada siapa? Dengan akibat atau hasil apa? (who? Says what? In which channel? To whom? With what effect?) sehingga pelaksaanaan berjalan dengan efektif.

Dari segi sumber daya manusia Parik Paga Nagari Sungai Pua saat ini belum maksimal karena dalam perekrutan menjadi anggota, orang yang terpilih menjadi anggota Parik Paga tidak melalui seleksi yang memiliki kriteria-kriteria layaknya seorang Parik Paga. Namun Parik Paga direkrut hanya berdasarkan perwakilan jorong yang dipilih oleh walinagari selaku penanggung jawab Parik Paga tersebut. Sebagaimana penelitian dari Sanjaya (2017) dan Hamudy (2014) menyatakan bahwa untuk menemukan sosok pelaksana dibutukan kriteria-kriteria yang bisa menjalankan tugas dan wewenangnya agar tugas dan wewenang tersebut bisa dijalankan, namun disisi lain akan sulit ditemukan orang-orang tersebut apabila masyarakat tersebut memiliki tingkat pendidikan yang rendah.

Selanjutnya jalannya suatu peran tersebut terletak pada sumber daya. Meskipun tugas dan wewenang tersebut sudah dikomunikasikan dengan baik (transformasi, kejelasan, dan konsisten). Tetapi apabila pelaksana kekurangan sumber daya manusia untuk melaksanakan, pelaksanaan akan tidak berjalan efektif. Selain itu pendapat Edward III (Subarsono, 2011: 90) bahwa sumber daya manusia penting dalam mendukung pelaksanaan peran antara lain anggota atau SDM. Hal tersebut menjadi nyata bahwa sumber daya manusia dapat mempengaruhi pelaksanaan peran.

Masyarakat sangat setuju dengan adanya Parik Paga di tengah lingkungan mereka walaupun masyarakat belum mengatahui Parik Paga secara mendalam. Hal ini terlihat dari segala masalah yang dihadapi oleh masyarakat sangat terbantu dengan adanya Parik Paga sebagai pihak yang dapat menyelesaikan persoalan-persoalan yang berkaitan dengan ketertiban dan keamanan. Masalah yang harusnya sudah melibatkan kepolisian dengan adanya Parik Paga masalah tersebut bisa terselesaikan ditangan Parik Paga. Masyrakat merasa nagarinya bisa aman dan tentram karena adanya Parik Paga. Sejalan dengan penelitian Sanjaya (2017) dan Bahar (2016) yang menjelaskan kesadaran masyarakat akan mempengaruhi bagaimana peran dilaksanakan. Kesadaran masyarakat akan menjadi faktor pendukung pelaksanaan apabila semua masyarakat mendukung adanya pelaksana dalam menjalankan peran.

Sedangkan

kesadaran masyarakat akan menjadi faktor penghambat apabila tingkat kesadaran masyarakat rendah karena masyarakat merupakan wadah dari pelaksanaan 
peran tersebut. Sesuai dengan pendapat Edward III (Subarsono, 2011: 90) bahwa ketika masyarakat memiliki disposisi yang baik, maka kebijakan akan berjalan baik seperti yang diinginkan oleh pembuat peran. Ketika masyarakat memiliki pandangan atau sikap yang berbeda dengan pelaksanaan, maka proses pelaksanaan peran juga akan menjadi tidak efektif.

Terakhir dari segi struktur birokrasi yang ada pada Parik Paga sudah dapat melambangkan peran, fungsi, tugas dan wewenangnya. Artinya struktur Parik Paga ini sudah dapat dikatakan baik terlihat dari adanya seksi-seksi dari struktur Parik Paga yang melambangkan tugas dan fungsinya sebagai Parik Paga. Bagi Parik Paga sendiri dapat mengetahui tanggung jawabnya dibidang apa dan mengetahui dengan siapa mereka harus berkoordinasi. Hal ini Sesuai dengan Meliala (2013) untuk dapat berdaya guna dan berhasil guna secara optimal, perlu adanya Standar Operasional Prosedur (SOP) yang tetap bagi pelaksana dalam melaksanakan tugas. Pengawasan dilakukan oleh walinagari sendiri sebagai penanggung jawab Parik Paga. Edward III (Subarsono, 2011: 90) berpendapat bahwa sumber-sumber penting dalam mendukung pelaksanaan peran antara lain struktur birokrasi yang terdiri dari adanya SOP dan pembagian kerja.

\section{Hambatan-Hambatan Parik Paga dalam Menjaga Ketertiban dan Keamanan di Nagari Sungai Pua}

$\begin{array}{lrr}\text { Ada tiga } & \text { hambatan yang } \\ \text { ditemui Parik } & \text { Paga } & \text { selama } \\ \text { melaksanakan perannya } & \text { menjaga } \\ \text { ketertiban dan keamanan } & \text { Nagari }\end{array}$

Sungai Pua. Hambatan itu adalah masalah fasilitas sarana dan prasarana, anggaran dana dan regulasi atau aturan. Dilihat dari fasilitas sarana dan prasarana masih minim terlihat dari alat komunikasi dan trasportasi tidak dimiliki Parik Paga. Fasilitas sarana dan prasrana dari Parik Paga justru menggunakan fasilitas sarana dan prasarana dari pribadi masing-masing seperti kendaraan roda dua yang digunakan Parik Paga untuk berpatroli keliling kampung adalah milik pribadi.

Sesuai dengan hasil penelitian dari Sanjaya (2017), Prasetyo (2014), dan Yohannes (2015) bahwa untuk bisa lancar dan mudah pelaksanaan dalam menjalankan perannya pelaksana butuh fasilitas sarana dan prasarana yang memadai. Fasilitas sarana dan prasarana merupakan penunjang kegiatan bagi pelaksanaan. Dengan adanya sarana dan prasarana yang kurang memadai tentu akan menghambat pelaksanaan peran, namun untuk memenuhi fasilitas sarana dan prasarana ini cukup sulit. Pasalnya fasilitas sarana dan prasarana dianggarkan kepada pemerintah yang membutuhkan waktu yang lama agar bisa terealisasikan. Pelaksana peran sekarang ini hanya mendapatkan baju seragam. Menurut Bahar (2016) tanpa adanya sarana atau fasilitas tertentu, maka tidak mungkin penegakan hukum akan berjalan lancar dan mustahil untuk penegak hukum akan mencapai tujuannya.

Selanjutnya anggaran dana untuk mereka beroperasi seperti turun ke lapangan, melakukan sosialisasi, atau mengatasi masalah yang berkaitan dengan ketertiban dan keamanan justru menggunakan uang 
saku sendiri karena Parik Paga yang merupakan organisasi sosial kemasyarakatan yang hanya bersifat sosial bukan pemerintahan yang bergerak karena kecintaan terhadap nagari. Gaji untuk Parik Paga sama sekali tidak ada, bahkan untuk melaksanakan tugas sedikitpun mereka tidak mendapatkan dana operasionalnya. Padahal tanggung jawab atas tugasnya yang berat tidak sebanding dengan dana yang tidak mereka peroleh sedikitpun menjadikan tanggung jawab atas tugasnya semakin berat dan sulit untuk dilaksanakan. Sesuai dengan hasil penelitian Sanjaya (2017) dan Hamudy (2014) bahwa pelaksanaan peran menjaga ketertiban dan keamanan masyarakat Bali ini juga terhambat oleh dana, mereka tidak ada digaji sedikitpun mereka menjadi pelaksana peran menjaga ketertiban dan keamanan ini hanya yang mau dan bersedia (hanya luputan).

Adanya ketidaksesuaian regulasi yang ada saat ini tentang tugas dan wewenang Parik Paga dengan hukum adat yang ada Minangkabau. Hal ini terlihat dari adanya pertikaian antara Parik Paga dengan kaum adat dalam mengambil tindakan terhadap masyarakat yang melakukan pelanggaran. Regulasi yang belum diatur membuat Parik Paga dalam menjaga ketertiban dan keamanan menjadi tidak berjalan seperti kebiasaan masyarakat yang berjudi pada saat malam adat. Parik Paga hanya bisa mengingatkan masyarakat karena kebiasaan tersebut dalam regulasinya tidak ada mengatur tentang hal itu.

Regulasi mengenai anggaran dana Parik Paga pun tidak ada di atur dalam peraturan apapun. Adapun menurut penelitian Sanjaya (2017) juga mengatakan bahwa hambatan yang ditemui dalam pelaksana peran menjaga ketertiban dan keamanan adalah minimnya regulasi sehingga tidak ada wewenang pelaksana dalam menindak setiap bentuk pelanggaran yang dilakukan masyarakat. Dasar hukum yang masih lawas sedangkan konsepsi dan filosofi tentang pelaksana sudah berbeda maka pelaksana akan sulit menjalankan tugas pokok dan fungsinya secara utuh (Hamudy, 2014: 265)

\section{Upaya untuk mengatasi hambatan- hambatan Parik Paga dalam Menjaga Ketertiban dan Keamanan di Nagari Sungai Pua}

Menurut Satjipto Rahardjo (Henny. 2010: 30) ketertiban adalah sesuatu yang dinamis. Ketertiban dan keamanan sama-sama ada dalam asas proses sosial yang bersambung (continum). Keduanya tidak berseberangan, tetapi sama-sama ada dalam satu asas kehidupan social. Ketertiban bersambung dengan kekacauan dan kekacauan membangun ketertiban baru. Dalam ketertiban ada benih-benih kekacauan, sedangkan dalam kekacauan tersimpan bibit-bibit ketertiban. Keduanya adalah sisi dari mata uang yang sama. Dalam melaksanakan tugasnya ada beberapa hambatan yang ditemui seperti fasilitas sarana dan prasarana, anggaran maupun regulasi.

Untuk mengatasi tersebut maka solusi yang ditawarkan yaitu sosialisasi yang dilakukan dengan dua metode yaitu sosialisasi secara langsung dan tidak langsung. Sosialisasi langsung dapat dilakukan dengan cara membuat pertemuan langsung atau khusus kepada 
Volume 1 No. 42018

masyarakat mengenai peran Parik Paga dalam menjaga ketertiban dan keamanan, pertemuan tersebut dapat berbentuk tanya jawab atau dapat berbentuk seminar. Selanjutnya sosilisasi secara tidak langsung dapat dilakukan dengan cara melibatkan Parik Paga setiap ada kegiatan nagari, membuat selebaran mengenai Parik Paga atau mendatangi masyarakat untuk mengatasi masalah yang dihadapi. Menurut Sanjaya (2017) mereka mengatakan sosialisasi perlu di lakukan demi meningkatkan kesadaran masyarakat dengan cara menyosialisasikan peran kepada masyarakat di setiap kesempatan. Seperti halnya yang dikatakan oleh Mead (Badrudin, 2017: 37) sosialisasi merupakan suatu proses dimana di dalamnya terjadi pengambilan peran (role taking) untuk mengetahui peranan yang harus dijalankannya serta peranan yang dijalankan orang lain.

Pemerintahan nagari, Parik Paga dan masyarakat setuju mengupayakan anggaran dana atau fasilitas sarana dan prasarana yang lengkap melalui regulasi-regulasi yang harus dirancang dan dilahirkan agar dana yang didapatkan baik itu dari dana nagari, APBD atau dana dari pusat bisa dianggarkan untuk dana operasional atau gaji Parik Paga dalam melaksanakan tugasnya. Serta juga dapat dianggarkan demi lengkapnya fasilitas sarana dan prasaran Parik Paga. Pembuatan regulasi tentang pelanggaran-pelanggaran yang belum diatur pada regulasi saat ini perlu diciptakan agar pelanggaranpelanggaran tidak terjadi lagi.

Upaya untuk mengoptimalkan pelaksanaan peran menurut Kinasih
(2018) adalah perlu adanya suatu peraturan yang dituangkan pada peraturan-peraturan yang ada agar memperkuat peran serta masyarakat dalam menjaga lingkungan sendiri. Seperti yang dikatakan Soekanto (Bahar, 2016: 30) yaitu semakin baik suatu peraturan hukum akan semakin memungkinkan penegakannya. Sebaliknya, semakin tidak baik suatu peraturan hukum akan semakin sukarlah menegakkannya.

Upaya terakhir adalah Parik Paga perlu diberikan pelatihan untuk meningkatkan kecerdasan emosional serta peningkatan kemampuan, keahlian dan kepribadian ke arah yang lebih baik. Pelatihan tidak hanya bersifat psikis saja namun untuk fisik juga diperlukan seperti bela diri dan yang lainnya mengingat dari peran Parik Paga yang mengharuskan Parik Paga untuk turun ke lapangan menyelesaikan secara langsung persoalan yang telah ada tidak menutup kemungkinan Parik Paga akan mendapatkan tekanan atau perlawanan dari pihak yang bersengketa. Sesuai dengan hasil penelitian dari Sanjaya (2017) bahwa pelaksana yang menjaga ketertiban dan keamanan agar ditingkatkan pengetahuan dan keterampilannya dengan mengikuti pelatihan-pelatihan yang ada baik yang diadakan oleh pihak kepolisian ataupun pihak pemerintah. Meliala (2013) juga mengatakan bahwa upaya ini dilakukan ditujukan supaya gerak dan langkah pelaksana peran semaksimal terhindar dari tindakan-tindakan yang menyimpang.

\section{KESIMPULAN}

Berdasarkan temuan peneliti dan pembahasan dapat disimpulkan 
bahwa pelaksanaan peran Parik Paga jika dilihat dari empat variabel diatas bahwa pemerintahan nagari dan Parik Paga dalam melakukan sosilisasi kepada masyarakat dan kualitas sumber daya manusia Parik Paga masih kurang optimal. Sikap masyarakat terhadap adanya Parik Paga dan struktur birokarasi Parik Paga sudah dapat dikatakan baik. Berdasarkan pelaksanaan peran tersebut maka akan mempengaruhi pelaksaan peran yang dilakukan oleh Parik Paga seperti anggaran dana, sarana dan prasarana, dan regulasi atau aturan dari berbagai hambatan tersebut yang mendominasi adalah anggaran. Anggaran dana mendominasi karena anggaran dana yang dianggarkan untuk Parik Paga tidak ada sama sekali. Jadi ketika anggaran dana itu ada maka kehadiran atau keaktifan dari anggota Parik Paga tersebut akan tinggi namun sebaliknya jika tidak ada anggaran dana maka akan mengakibatkan Parik Paga yang pasif dalam Parik Paga.

Kemudian dengan adanya hambatan-hambatan yang ditemui oleh Parik Paga dalam melaksanakan perannya untuk menjaga ketertiban dan keamanan maka diperlukan sebuah upaya dalam mengatasi hal tersebut yaitu menyosialisasikan Parik Paga kepada masyarakat, membuat regulasi atau aturan, dan mengadakan pelatihan untuk Parik Paga. Implikasi penulisan artikel ini terhadap penelitian lainnya adalah dapat membantu penelitian dalam memahami apa sebenarnya yang melatarbelakangi kurangnya pelaksanaan dari suatu organisasi keamanan dan ketertiban yang ada di nagari Serta penelitian ini memberikan bantuan kepada peneliti lain dalam mengetahui hambatan dalam melaksanakan peran pada suatu organisasi serta upaya dalam mengatasi hal tersebut.

\section{DAFTAR PUSTAKA}

Azhari, Chintiya Ayu. (2018). Strategi Mengenal Khalayak Bhabinkamtibmas

(Bhayangkara Pembinaan Kemanan dan Ketertiban Masyarakat) Polsekta Samarinda Utara dalam Membangun Kemitraan Dengan Masyarakat di Kelurahan Mugirejo. Jurnal Ilmu Komunikasi. 6(1). Hlm 128-142

Badrudin, S., Trisiah, A., dan Hariyanti, D. (2017). Strategi Humas Polres dalam Mensosialisasikan Pencegahan Pencurian Kendaraan Bermotor. Jurnal Komunikasi Islam dan Kehumasan. 1(2). Hlm 32-58

Bahar, H., dan Haris, H. (2016). Persepsi Masyarakat terhadap Keberadaan Forum Keamanan dan Ketertiban Masyarakat (Studi di Desa Panciro Kecamatan Bajeng Kabupaten Gowa). Jurnal Tomalebbi. 3(2). Hlm 26-35

Hamudy, Moh. I. A. (2014). Eksistensi Satuan Perlindungan Masyarakat. Jurnal Bina Praja. 6(4). Hlm 261-268

Henny, Purwanti dan Misnarti. (2010).

Usaha Penertiban dan

Pembinaan Pedagang Kaki Lima di Kabupaten Lumajang. Jurnal Hukum Argumentum. 10(1). Hlm 29-42

Kinasih, W dan Pramono, J. (2018). Optimaslisasi Peran SATLINMAS di Kelurahan Gilingan Kecamatan Banjar Sari 
Kota Surakarta. Jurnal Ilmu Administrasi Publik. 3(1). Hlm 25-32

Meliala, D. Mikhael. (2013). Analisis Yuridis Kewenangan Satuan Polisi Pamong Praja dalam Penegakan Peraturan Mentri Dalam Negeri No. 26 Tahun 2005 (Studi Kabupaten Simalungun). Jurnal Hukum dan Negara. 1(1). Hlm 1-20

Prasetyo, Agus Eko. (2014). Peranan Lurah dalan Penyelenggaraan Ketentraman dan Ketertiban di Kelurahan Sidodadi Kecamatan Samarinda Ulu. Jurnal Ilmu Pemerintahan. 2(4). Hlm. 33263340

Sanjaya, Putu Sutaryadi dan Agustana, Putu. (2017). Peranan Pecalang dalam Menjaga Keamanan dan Ketertiban Desa Pakraman di Desa Pakraman Kalubukbuk. Locus Majalah Ilmiah Fisip. 7(1). Hlm 27-42

Subarsono, AG 2005. Analisis Kebijakan Publik (Konsep, Teori dan Aplikasi). Yogyakarta: Pustaka Pelajar

Wenxiu, Peng. (2015). Analysis of New Media Communication Based on Lasswell's "5W" Model. Journal of Educational and Social Research. 5(3). Hlm 245250

Yohannes, Sakai. (2015). Peranan Bintara Pembina Desa (Babinsa) dalam Menjaga Keamanan dan Ketertiban Masyarakat (Studi Kasus di Desa Setulang dan Desa Gong Solok Kecamatan Malinau Selatan Hilir Kabupaten Malinau. Jurnal Pemerintahan Integratif. 3(2). Hlm 307-322 